\title{
The Interaction between Stock Prices and Commodity Prices: East Europe and Central Asia Countries
}

\author{
Asst. Prof. Dr. Mustafa Ildırar (Çukurova University, Turkey) \\ Asst. Prof. Dr. Erhan İşcan (Çukurova University, Turkey)
}

\begin{abstract}
The sharp increase in commodity prices since 2000s has important effects on many economic variables. Especially the upward trend in commodity prices had substantial effects on stock prices. The literature has continuing and growing interest to the dynamics of commodity price and their significant impact on economic and financial developments. There is growing evidence that commodity prices, stock prices moved together, and that the correlations between them have increased. Many studies investigated the interaction between stock prices and real and commodity prices and find strong interaction for developed countries. However, the effect of the commodity prices on stock markets in relatively less investigated for ECA countries. The purpose of this study is to investigate the long-run relationship between commodity prices and stock prices in ECA countries can by using a panel cointegration test.
\end{abstract}

\section{Introduction}

The commodities especially oil, wheat, iron and rubber have an important role in economics because of they are the main components of many common goods in our lives. Especially an increases or a decrease in the commodity prices affects all of the economies in the world. In the last decade, the prices of many commodities volatility, with simultaneous and alternating phases of rising and falling trends. As shown in Figure $1 \& 2$ which displays All Commodity Price Index and Food Price Index indicates 2008 financial crisis and the decrease in last 12 months. Because of this, the prices of many commodities are the central issue for the world economy. Therefore, G20 emphasizes on volatility of commodity prices in its September 2009 Pittsburgh summit.

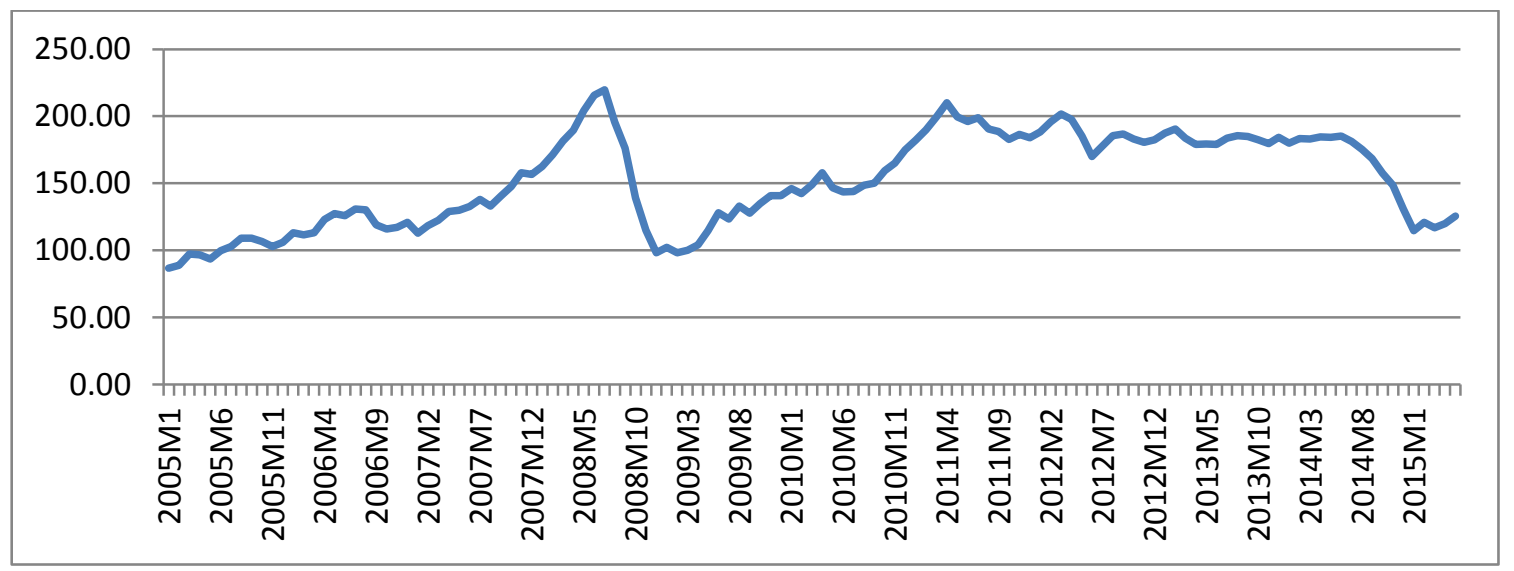

Table1. All Commodity Price Index, $2005=100$, includes both Fuel and Non-Fuel Price Indices Source: IMF

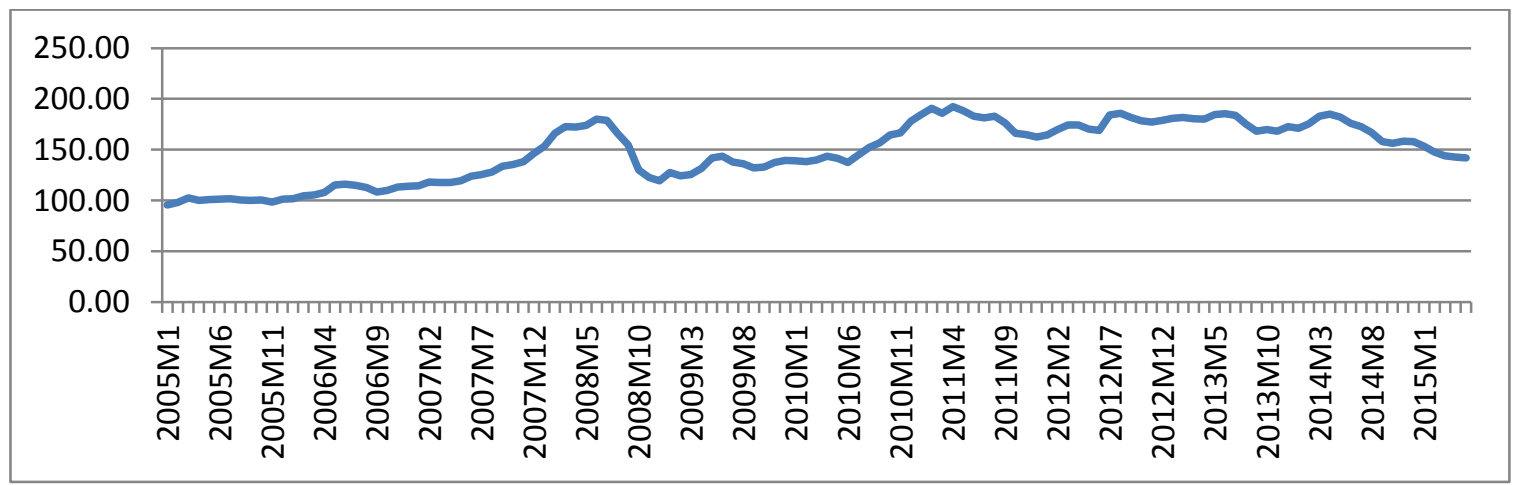

Table 2. Food Price Index, $2005=100$, includes Cereal, Vegetable Oils, Meat, Seafood, Sugar, Bananas, and Oranges Price Indices Source: IMF

Commodities are traded every day in commodity market as a financial instrument and a raw material for all commodities that we use in daily life. Commodity prices are important for the economy because they directly affect the prices. Moreover, commodities have effects on stock market as they are used as financial instrument 
and because of the effect on profitability of the corporate business. Therefore, analyzing the links between commodity and stock markets is very important for the investors, investment environment, economists, and economies.

Consequently, commodities influence world economy by affecting prices in fact. These prices may be commodity prices or share prices. Therefore, there will be a shock -negative or positive- to stock market that drags to an expansion or a recession the economy. The globalization causes the commodity price and stock markets in the world become more integrated. It was believed that the performance of stock markets would be affected by global commodity price.

This study contributes to the empirical literature about the relationships between stock and commodity markets. In addition, this is an additional study to the empirical literature, which focused on the dynamics of the relation between commodity and stock markets. These findings also help us assess the macroeconomic implications of commodity price shocks for the ECA countries. The paper is organized as follows: Definitions of the markets and interaction is reviewed in section 2, literature is reviewed in section 3, Methodology and data is presented and results are given in section 4, and results are concluded in section 5.

\section{Commodity Markets, Stock Markets and Interactions between Commodity Prices and Stock Prices}

Commodities consist of the basic materials and natural resources used in virtually all production and manufacturing processes. Commodity market is a market where the commodities are traded. There are various types of commodities include "hard commodities" and "soft commodities" in the market. Hard commodities are those resources exist naturally and must be extracted for example gold, oil, copper, etc. While soft commodities are products mostly from agricultural such as corn, wheat, sugar, soybeans, etc. (Keong et al., 2014). On the other the commodity market enables the investors to trade goods. In commodity markets buy or sell the shares of raw materials that are the components of our daily life.

Commodities are classified in different way by Farooki and Kaplinsky (2012) as follows.

\begin{tabular}{|c|c|c|c|}
\hline Primary Sector & Category & Major Use & Examples \\
\hline \multirow{5}{*}{ Soft Commodities } & Industrial Crops & Input in manufacturers & Timber \\
\hline & Fisheries & \multirow{4}{*}{$\begin{array}{l}\text { Final Consumption } \\
\text { (with limited processing) }\end{array}$} & Prawns, cod \\
\hline & Cereals & & Rice, wheat \\
\hline & Beverages & & Tea, Coffee, Cocoa \\
\hline & Livestock & & Cattle, Dairy products \\
\hline \multirow{4}{*}{ Hard Commodities } & Precious Metals & Input in manufactures & Gold, Silver, Platinum \\
\hline & Ferrous Metals & Infrastructure and Construction & Iron Ore and Steel \\
\hline & Non-Ferrous Metals & Input in manufacturers & Copper, Zinc, Lead, \\
\hline & Rare earths and metals & Input in manufacturers & Cerium Plutonium \\
\hline \multirow{4}{*}{ Energy } & Petroleum products & Fuel for industrial usage & Oil, Naturel Gas and \\
\hline & Coal & \multirow{3}{*}{ Final consumption } & Coal. \\
\hline & Nuclear & & Nuclear power \\
\hline & Renewables & & Renewable power \\
\hline
\end{tabular}

Table 3.Three Primary Commodity Families and Their Sector of Use Source: Farooki and Kaplinsky, 2011

Stocks represent individual shares of ownership in corporate businesses. Stocks can be purchased directly from corporate business or they can be bought from and sold to stock investors on stock exchanges around the world. These markets that stocks are traded between investors called as stock markets. Stock market which is part of the financial markets, perform the following functions in an economy: 1) Raising capital for business 2) Mobilizing savings for investment 3) Facilitate company growth 4) Redistribution of wealth 5) Corporate governance 6) Creates investment opportunities for small investors 7) Government raise capital for development projects 8) Barometer of the economy.

Both stocks and commodities are bought and sold on physical trading floors and through electronic trading networks without physical goods ever being exchanged. On the other hand, the fundamental differences between the stock market and the commodities market are the products they deal with, and thus the manner in which they work. The stock market deals in ownership shares of a company. In addition, while a share of stock represents an actual ownership in the company, it is essentially in electronic form but Commodities are actual iron, oil, wheat, or rubber and these are the components of the daily life commodities. Moreover, futures market contracts for commodities are like stocks, but they do not indicate ownership of a commodity; they indicate a right to own it from a contract. In the Table 4, we can see the economic indicators of major stock exchanges. 


\begin{tabular}{|c|c|c|c|}
\hline Stock Exchange & Headquarter & $\begin{array}{c}\text { Market Capitalization } \\
\text { (USD bn) }\end{array}$ & $\begin{array}{c}\text { Monthly Trade } \\
\text { Volume (USD bn) }\end{array}$ \\
\hline New York Stock Exchange & New York City & 19.223 & 1.520 \\
\hline NASDAQ OMX & New York City & 6.831 & 1.183 \\
\hline London Stock Exchange & London & 6.187 & 465 \\
\hline Japan Exchange Group & Tokyo & 4.485 & 1.278 \\
\hline Shanghai Stock Exchange & Shanghai & 3.986 & 155 \\
\hline Hong Kong Stock Exchange & Hong Kong & 3.328 & 184 \\
\hline Euronext & $\begin{array}{c}\text { Amsterdam-Brussels- } \\
\text { Lisbon-Paris }\end{array}$ & 3.321 & 800 \\
\hline Shenzhen Stock Exchange & Shenzhen & 2.285 & 120 \\
\hline TMX Group & Toronto & 1.939 & 142 \\
\hline Deutsche Börse & Frankfurt & 1.762 & \\
\hline
\end{tabular}

Table 4. Major stock exchanges of issued shares of domestic companies (as 30 January 2015) Resource: World Federation Exchange Monthly Reports

Table 5, reports stock market indicators for the some selected ECA countries examined. These ratios are also used in the work of Demirgüc et all. (1996) and Levine et all (1996) measure the role of stock market in economic growth.

Demirgüc et all. (1996) expressed that the ratio of stock market capitalization to GDP reflects the degree of activity with the liquidity and the turnover ratios. So that if we analyze the data we understand that the stock markets of ECA countries are quite large in terms of market capitalization, also these countries are considerable in terms of number of listed companies. The liquidity ratios are relatively very high in Turkey and Russian Federation while the other countries are low. This means that financial deepening is low in many ECA countries.

\begin{tabular}{|c|c|c|c|c|c|c|c|c|}
\hline \multirow[b]{2}{*}{ Country } & \multicolumn{2}{|c|}{$\begin{array}{c}\text { Stock Market } \\
\text { Capitalization } \\
\% \text { of GDP }\end{array}$} & \multicolumn{2}{|c|}{$\begin{array}{l}\text { Market Liquidity } \\
\text { Ratio \% of GDP }\end{array}$} & \multicolumn{2}{|c|}{$\begin{array}{c}\text { Turnover Ratio to } \\
\text { market } \\
\text { capitalization }\end{array}$} & \multicolumn{2}{|c|}{$\begin{array}{c}\text { Number of Listed } \\
\text { Domestic } \\
\text { Companies }\end{array}$} \\
\hline & 2005 & 2012 & 2005 & 2012 & 2005 & 2012 & 2005 & 2012 \\
\hline Armenia & 0.9 & 1.3 & 0.0 & 0.0 & 3.7 & 0.8 & 198 & 12 \\
\hline Georgia & 5.5 & 6.0 & 0.6 & 0.0 & 13.6 & 0.2 & 257 & 133 \\
\hline Kazakhstan & 18.4 & 11.5 & 1.9 & 0.5 & 14.9 & 3.3 & 62 & 74 \\
\hline Kyrgyzstan & 1.7 & 2.5 & 0.5 & 0.1 & 34.1 & 3.4 & 8 & 18 \\
\hline FRY Macedonia & 10.8 & 5.8 & 1.6 & 0.3 & 18.3 & 5.4 & 57 & 32 \\
\hline Montenegro & 46.5 & 94.6 & 4.6 & 1.1 & 14.8 & 1.2 & 19 & 33 \\
\hline Rus.Federation & 71.8 & 43.4 & 20.9 & 36.3 & 39 & 87.6 & 296 & 276 \\
\hline Serbia & 20.6 & 18.3 & 2.5 & 0.7 & 15.3 & 3.7 & 864 & 1086 \\
\hline Turkey & 33.4 & 39.1 & 41.7 & 44.2 & 154.9 & 136.5 & 302 & 405 \\
\hline Ukraine & 29.0 & 11.7 & 0.8 & 0.7 & 3.6 & 5.2 & 221 & 198 \\
\hline Uzbekistan & 0.3 & n.a & 0.3 & 0.2 & 184.7 & n.a & 114 & 132 \\
\hline
\end{tabular}

Table 5. Some Selected ECA Countries'Stock Market Indicators Resource: WorldBank, 2014

\section{Literature Review}

Over the last decade, increases in the commodity prices have an unexpected volatility. For the policymakers commodity prices and its significance of correlations with stock markets are at central issue in the world of economics. Furthermore, the analysis of relationships between commodity and stock markets is a topic of interest for financial players because many investment portfolios are included raw materials together with stock classes.

Sadorsky (1999) studied the relation between oil prices and stock prices by using a VAR model that includes a short-term interest rate and industrial production. They found that there is a relation between oil price and other variables (Sadorsky, 1999).

Hamilton (2003), Jimenez et all. (2005) and Kilian (2008) studied impact of oil prices on economic growth. They find that a shock on oil prices have an impact on economic growth.

Gorton and Rouwenhorst (2004) showed that commodity market price have a large impact on the stock price. 
Chiou and Lee (2009) studied the WTI daily oil prices on S\&P 500 stock returns data from 1992 to 2006 using a model with oil price fluctuations. They found that fluctuations in oil prices have impact on stock returns.

Choi and Hammoudeh (2010) studied the relation between commodity prices of Brent oil, WTI oil, copper, gold and silver, and the S\&P 500 index and found that commodity prices have effected portfolios in stock markets.

Filis et al. (2011) analyze the interaction between oil prices and stock markets by differentiating oil-importing and oil-exporting countries. Their study showed that there is an interaction between oil and stock prices for oilimporting and oil-exporting economies.

Killian and Vigfusson (2011) found that an unexpected increase in real price of oil affected economic growth.

To sum up, the commodity prices increasingly important role in explaining equity markets Wen et al. 2012, Büyükşahin and Robe, 2010, Tang and Xiong, 2010 revealed the financialization of commodities have complex relations between different commodities or the interactions between commodities and financial assets. Even further, Buyuksahin et al. (2010) found that commodity and stock markets could move like a "market of one" in times of fluctuations.

As this literature, review indicates that the interaction between commodity prices and stock prices needs new empirical findings about the interaction within the different countries.

\section{Model and Data}

This section defines variables and describes data. We collect a set of panel data from 10 of ECA countries over the period 2012M01-2015M05. Data frequency is the most important issue in examining the interaction between the stock prices and commodity prices. Data for 10 countries captures interaction between the commodities and the stock prices. Therefore, the monthly data is used in this study. The datas for all countries obtained from IMF International Financial Statistics (IFS) iLibrary system.

The datas are as follows:

\begin{tabular}{|l|l|}
\hline Data & Contents \\
\hline Stock Prices (SP) & Share Prices as index for every country \\
\hline Oil Price (OIL) & $\begin{array}{l}\text { Crude Oil (petroleum), Dated Brent, light blend 38 API, fob U.K., } \\
\text { US\$ per barrel }\end{array}$ \\
\hline Iron Price (IRON) & $\begin{array}{l}\text { China import Iron Ore Fines 62\% FE spot (CFR Tianjin port), US } \\
\text { dollars per metric ton }\end{array}$ \\
\hline Rubber Price (RUBBER) & $\begin{array}{l}\text { Rubber, Singapore Commodity Exchange, No. 3 Rubber Smoked } \\
\text { Sheets, 1st contract, US cents per pound }\end{array}$ \\
\hline Wheat Price (WHEAT) & $\begin{array}{l}\text { Wheat, No.1 Hard Red Winter, ordinary protein, FOB Gulf of } \\
\text { Mexico, US\$ per metric ton }\end{array}$ \\
\hline
\end{tabular}

Table 6. Data definitions

We consider the stock market prices as dependent variables for the stock market indicator. Due to the data restrictions, we use only four main commodity prices as independent variable. We selected oil, iron, rubber and wheat prices as commodity prices that affects the stock prices. These four commodities are the main commodities for the whole goods and services. Therefore, this selection of the variables is reasonable.

\subsection{Methods and Findings}

In this section, we will introduce the methods that used in the study and the resulting empirical findings. This study contributes to the empirical literature about the relationships between stock and commodity markets for the ECA countries. Panel unit root tests of Levin, Lin and Chu test is applied to test if there are unit roots in panel data sets. In the second step, Pedroni's panel cointegration test is used to examine the cointegrating relationship.

\subsection{Panel Unit Root Analysis}

Main issue before estimating the model is to test if the variables are stationary or not. We performed panel unit root test on the dependent and independent variables. We follow the approach of Levin, Lin \& Chu panel unit root test. Results of this test in levels and differences are reported in the Table 5. The LLC panel unit root test results in Table 5 suggests that both stock prices, oil prices, iron prices and rubber prices are I(1) variables. 


\begin{tabular}{|l|l|}
\hline Variables & Levin, Lin \& Chu \\
\hline Individual Intercept & \\
\hline SP & 0.97354 \\
\hline OIL & 2.30423 \\
\hline IRON & 2.15372 \\
\hline RUBBER & -1.29921 \\
\hline WHEAT & -1.59650 \\
\hline Individual Intercept and Trend & \\
\hline SP & 0.36339 \\
\hline OIL & 5.05918 \\
\hline IRON & 2.98896 \\
\hline RUBBER & 6.17715 \\
\hline WHEAT & -1.39116 \\
\hline Individual Intercept & \\
\hline$\Delta$ SP & $-16.7527^{* * *}$ \\
\hline$\Delta$ OIL & $-6.44536^{* * *}$ \\
\hline$\Delta$ IRON & $-7.22967^{* * *}$ \\
\hline$\Delta$ RUBBER & $-3.48752^{* * *}$ \\
\hline$\Delta$ WHEAT & $-3.78984^{* * *}$ \\
\hline Individual Intercept and Trend & \\
\hline$\Delta$ SP & $-15.6122^{* * *}$ \\
\hline$\Delta$ OIL & $-8.08513^{* * *}$ \\
\hline$\Delta$ IRON & $-7.62236^{* * *}$ \\
\hline$\Delta$ RUBBER & $-1.54904^{*}$ \\
\hline$\Delta$ WHEAT & $-3.39474^{* * *}$ \\
\hline
\end{tabular}

Table 7. Results for panel unit root test. The choice of lag levels is based on the Schwarz Information Criterion. The LLC tests were computed using the Bartlett kernel with automatic bandwidth selection. ***, ** and * indicate significance at the $1 \%, 5 \%$ and $10 \%$ levels.

\subsection{Empirical Results}

All of the variables under investigation are integrated of order one so we can examine whether a long-run relationship exists. We examined the long-run relationship between the variables. Pedroni at his pioneer study in 2000 and 2004 developed cointegrated panels illustrated by heterogeneity and fixed effects. Pedroni proposed seven statistics to test long-run relationship. The results of Pedroni's panel cointegration test are reported in Table 8. Pedroni panel cointegration tests have no any evidence of cointegration. For the six of seven statistics significantly we cannot reject the null of no cointegration. Thus, stock, oil, iron, rubber and wheat prices do not move together in the long run.

\begin{tabular}{|l|l|l|}
\hline Dependent Variable: Stock Prices \\
\hline \multicolumn{2}{|l|}{ Independent Variables: Oil Prices, Iron Prices, Rubber Prices, Wheat Prices } \\
\hline Intercept & \multicolumn{1}{|l|}{ Statistic } & \\
\hline Panel v-Statistic & 1.264224 & Prob. \\
\hline Panel rho-Statistic & -0.088014 & 0.1031 \\
\hline Panel PP-Statistic & -1.305742 & 0.4649 \\
\hline Panel ADF-Statistic & -0.203417 & 0.0958 \\
\hline & Statistic & 0.4194 \\
\hline Group rho-Statistic & 0.224497 & Prob. \\
\hline Group PP-Statistic & -1.830245 & 0.5888 \\
\hline Group ADF-Statistic & -0.212380 & 0.0336 \\
\hline Intercept and Trend & & 0.4159 \\
\hline Panel v-Statistic & Statistic & \\
\hline Panel rho-Statistic & -0.056683 & Prob. \\
\hline Panel PP-Statistic & 0.689856 & 0.5226 \\
\hline Panel ADF-Statistic & -1.372621 & 0.7549 \\
\hline & -0.207832 & 0.0849 \\
\hline Group rho-Statistic & Statistic & 0.4177 \\
\hline Group PP-Statistic & 0.742869 & Prob. \\
\hline Group ADF-Statistic & -2.185683 & 0.7712 \\
\hline
\end{tabular}

Table 8. Pedroni's panel cointegration tests. The null hypothesis is that there is no cointegration. Under the null hypothesis all the statistics are distributed as standard normal distributions. 


\section{Conclusion}

In this paper, we have examined the relationship between stock market and commodity prices in a panel cointegration. The interaction during the entire sample period (January 2012-May 2015) is investigated. Using Pedroni's panel cointegration test to investigate the relationships between the commodity price variables and stock variables shows important results. Our results show that there is no relation between commodity and stock markets. Estimates indicate that the interaction between commodity market and stock market is uncertain. We need to expand the study a wide area. On the other hand, this result is expected because of the stock market indicators. In the Section 2 we said that the liquidity ratios are relatively very high in Turkey and Russian Federation while the other countries are low. Therefore, we may expect that if the ratios there will be no relation between the commodity prices and the stock prices.

\section{Acknowledgments}

This study was supported by Research Fund of the Cukurova University.

\section{References}

- Avalos, F. (2011)-“Commodity prices: Microeconomic drivers and emerging risks for Latin America”, Papers and Proceedings of the VI International Conference, Challenges of macroeconomic policy in emerging and developing economies, Fondo Latinoamericano de Reservas, October, https://www.flar.net/documentos/4369_Fernando_Avalos.pdf.

- Black, A. et al. (2014)-“Forecasting Stock Returns: Do Commodity Prices Help?”, Journal of Forecasting,33(8)

- Büyükşahin, B. Et al. (2010)-“Commodities and Equities: Ever a "Market of One?" The Journal of Alternative Investments, Winter 2010, Vol. 12, No. 3: p. 76.

- Cooray, A. (2010)- “Do stock markets lead to economic growth?”, Journal of Policy Modelling, 32 (2010), p. 448.

- Creti, A. et al. (2012)- "On the links between stock and commodity markets' volatility”, CEP II, Working Paper No:2012-20

- Chiou, Jer-Shiou; Lee, Yen-Hsien. (2009) "Jump dynamics and volatility: Oil and the stock markets", Energy, 34.6: 788-796.

- Demiralay, S. and Ulusoy, V. (2014)- "Links Between Commodity Futures And Stock Market: Diversification Benefits, Financialization And Financial Crises”, MPRA Paper No. 59727

- Demirgüç-Kunt, Asli; Levine, Ross, (1996), "Stock markets, corporate finance, and economic growth: an overview”, The World Bank Economic Review, 223-239.

- Farooki, M. Z. and R. Kaplinsky (2011)- The Impact of China on Global Commodities: The Disruption of the World's Resource Sector, London: Routledge

- Filis, George; Degiannakis, Stavros; Floros, Christos, (2011), "Dynamic correlation between stock market and oil prices: The case of oil-importing and oil-exporting countries", International Review of Financial Analysis, 20.3: 152-164.

- Gorton, Gary; Rouwenhorst, K. Geert, (2006), "Facts and fantasies about commodity futures", Financial Analysts Journal, 2006, 62.2: 47-68.

- Hamilton, James D.,(2003), “What is an oil shock?”. Journal of econometrics, 113.2: 363-398.

- Choi, Kyongwook; Hammoudeh, Shawkat, (2010), "Volatility behavior of oil, industrial commodity and stock markets in a regime-switching environment” Energy Policy, 2010, 38.8: 4388-4399.

- Jiménez-Rodrìguez, Rebeca; Sànchez, Marcelo, (2005), “Oil price shocks and real GDP growth: empirical evidence for some OECD countries”, Applied economics, 37.2: 201-228.

- Johnson, R., Soenen, L. (2009)- "Commodity Prices and Stock Market Behavior in South American Countries in the Short Run”, Emerging Markets Finance and Trade, 45:4, p. 69.

- Keong, C.M, et al. (2014)- Relationship Between Commodities Market and Stock Market: Evidence From Malaysia and China, Universiti Tunku Abdul Rahman Research Project

- Kilian, Lutz, (2008) "Exogenous oil supply shocks: how big are they and how much do they matter for the US economy?", The Review of Economics and Statistics, 90.2: 216-240.

- Kilian, Lutz; Vigfusson, Robert J.(2011), “Are the responses of the US economy asymmetric in energy price increases and decreases?", Quantitative Economics, 2011, 2.3: 419-453.

- Lombardi, M., Ravazzolo, F. (2013)- On the correlation between commodity and equity returns: implications for portfolio allocation, BIS Working Papers No 420 
- Nangolo, C., and Musingwini (2012)-“Emprical correlation of mineral commodity prices with Exchangetraded mining stock prices”, JSAIMM,111(7), p. 459.

- Pedroni, Peter, (2004), "Panel cointegration: asymptotic and finite sample properties of pooled time series tests with an application to the PPP hypothesis", Econometric theory, 20.03: 597-625.

- Pedroni, Peter, (2000), "Fully Modified OLS for Heterogeneous Cointegrated Panels," Department of Economics Working Papers 2000-03, Department of Economics, Williams College.

- Sadorsky, P. (1999)-“'Oil pice shocks and stock market activity”, Energy Economics 21, p. 449.

- Soucek, Michael (2013)-“Crude oil, equity and gold futures open interest co movements”, Energy Economics 40 (2013), p.306.

- Tang, K., Xiong, W. (2012)-“Index Investment and the Financialization of Commodities”, Financial Analysts Journal, Volume:68, Number: 6, p. 54.

- Thuraisamy, K., et all. (2012)-“The ralationship between Asian equity and commodity futures market”, Financial Econometric Series, SWP 2012/07

- Zapata, H., et all (2012)- "Historical Performance of Commodity and Stock Markets", Journal of Agricultural and Applied Economics, 44,3 (August 2012), p. 339. 